\title{
Fatty acid-induced mitochondrial uncoupling in adipocytes as a key protective factor against insulin resistance and beta cell dysfunction: do adipocytes consume sufficient amounts of oxygen to oxidise fatty acids?
}

\author{
J. A. Maassen • J. A. Romijn • R. J. Heine
}

Received: 17 January 2008 / Accepted: 2 February 2008 / Published online: 4 March 2008

(C) The Author(s) 2008

Keywords Adipocytes $\cdot$ Fatty acids $\cdot$ HAART . Mitochondria - Type 2 diabetes mellitus

\section{Abbreviation \\ HAART highly active anti-retroviral therapy}

To the Editor: The phenotype of patients with various forms of congenital lipodystrophy has indicated that proper storage of triacylglycerol in peripheral adipocytes is essential to prevent formation of ectopic fat deposits and development of type 2 diabetes [1]. A similar situation with induced peripheral lipodystrophy and elevated risk for type 2 diabetes is seen in patients undergoing highly active anti-retroviral therapy (HAART). In these patients, there is a $30-50 \%$ decline in mitochondrial copy number as a result of HAART [2].

J. A. Maassen $(\bowtie)$

Department of Molecular Cell Biology,

Leiden University Medical Centre,

Postal Zone S01-P, P.O. Box 9600, 2300RC Leiden,

The Netherlands

e-mail: j.a.maassen@lumc.nl

J. A. Maassen · R. J. Heine

Department of Endocrinology/Diabetes Centre,

VU University Medical Centre,

Amsterdam, The Netherlands

\section{J. A. Romijn}

Department of Endocrinology and Metabolic Diseases,

Leiden University Medical Centre,

Leiden, The Netherlands

\section{R. J. Heine}

Eli Lilly and Company, Lilly Corporate Center,

Indianapolis, IN, USA
Based on these and other observations, we have recently put forward the hypothesis that one of the functions of mitochondria in adipose tissue is to prevent leakage of fatty acids into the circulation [3]. This mitochondrial activity attenuates the development of ectopic triacylglycerol deposits in the liver and other tissues that would otherwise contribute to the development of whole body insulin resistance and pancreatic beta cell damage. Mitochondria contribute to efficient confinement of fatty acids within adipocytes by oxidative removal of fatty acids, liberated from the triacylglycerol pool, by uncoupled beta oxidation. In addition, mitochondria may provide glyceroneogenic substrates, which contribute to reesterification of fatty acids. As a net result, there are less fatty acids available to the circulation for redistribution to other compartments of the body [3]. A recent study provided supporting evidence for this concept by showing that the mitochondrial DNA copy number in human adipocytes is positively associated with lipogenesis in adipocytes [4].

Recently, Frayn et al. have argued against this biochemical mechanism [5]. They point out that fatty acid oxidation is not a major pathway in white adipocytes and that oxygen consumption by adipose tissue is insufficient to oxidise substantial amounts of fatty acids [6].

We fully agree with the point made by the authors that fatty acid oxidation by adipocytes is not a major pathway compared with muscle. However, we hold a different view on the quantitative interpretation of these data: in our model there is no need for a high rate of fatty acid oxidation in adipose tissue per time unit, as fatty acid redistribution from peripheral tissue to the liver is a slow process, taking several years. For instance, in individuals in whom mitochondrial copy number is acutely reduced as result of starting HAART, it takes 18-24 months before redistribution of body fat becomes clinically manifest [7]. 
Therefore, the amount of fatty acids that undergoes redistribution per time unit is very small. Thus, mitochondria in adipocytes only need to remove a small amount of fatty acids per time unit to protect against redistribution of body fat. By using the oxygen consumption data of Frayn et al. and others [5, 6] or using similar data from other studies $[8,9]$, one can calculate that oxygen consumption by adipose tissue is sufficient to prevent redistribution of $>1.5 \mathrm{~kg}$ of fat out of $10 \mathrm{~kg}$ of peripheral adipose tissue to the liver within a 3 year period, a realistic clinical situation.

Therefore, in our opinion, adipose tissue is able to oxidise substantial amounts of fatty acids over a long period by mitochondrial beta oxidation. This process may over time attenuate ectopic deposition of those fatty acids. Since mitochondria also contribute to formation of glycerol 3phosphate, needed for re-esterification of fatty acids within adipocytes, mitochondria in adipocytes have the ability to protect the organism to a certain extent against leakage of fatty acids into the circulation and thus, redistribution of body fat. As Frayn et al. [5] have pointed out, brown adipose tissue is indeed more active in uncoupled oxidative disposal of fatty acids compared with white tissue. Recent evidence also suggests that brown adipose tissue is present in variable amounts and at multiple sites in humans, contrary to earlier reports [10]. This recently recognised situation further enhances the capacity of the adipose compartment to remove fatty acids through uncoupled beta oxidation.

In order to understand the mechanism by which mitochondria in adipocytes contribute to the control of body fat distribution during the development of the metabolic syndrome, additional studies are needed, comprising quantification of fatty acid fluxes in relation to reesterification and oxidation in adipose tissue. These studies should include study of adipose tissue from individuals with normal glucose tolerance and from those with developing glucose intolerance.
Duality of interest The authors declare that there is no duality of interest associated with this manuscript.

Open Access This article is distributed under the terms of the Creative Commons Attribution Noncommercial License which permits any noncommercial use, distribution, and reproduction in any medium, provided the original author(s) and source are credited.

\section{References}

1. Capeau J, Magré J, Lascols O et al (2005) Diseases of adipose tissue: genetic and acquired lipodystrophies. Biochem Soc Trans 33:1073-1077

2. Brinkman K, Smeitink JA, Romijn JA, Reiss P (1999) Mitochondrial toxicity induced by nucleoside-analogue reverse-transcriptase inhibitors is a key factor in the pathogenesis of antiretroviraltherapy-related lipodystrophy. Lancet 354:1112-1115

3. Maassen JA, Romijn JA, Heine RJ (2007) Fatty acid-induced mitochondrial uncoupling in adipocytes as a key protective factor against insulin resistance and beta cell dysfunction: a new concept in the pathogenesis of obesity-associated type 2 diabetes mellitus. Diabetologia 50:2036-2041

4. Kaaman M, Sparks LM, van Harmelen V et al (2007) Strong association between mitochondrial DNA copy number and lipogenesis in human white adipose tissue. Diabetologia 50: $2526-2533$

5. Frayn KN, Langin D, Karpe F (2008) Fatty acid-induced mitochondrial uncoupling in adipocytes is not a promising target for treatment of insulin resistance unless adipocyte oxidative capacity is increased. Diabetologia (in press). DOI 10.1007/s00125-007-0901-z

6. Coppack SW, Fisher RM, Gibbons GF et al (1990) Postprandial substrate deposition in human forearm and adipose tissues in vivo. Clin Sci (Lond) 79:339-348

7. Baril JG, Junod P, Leblanc R et al (2005) HIV-associated lipodystrophy syndrome: a review of clinical aspects. Can J Infect Dis Med Microbiol 16:233-243

8. Hallgren P, Sjöström L, Hedlund H, Lundell L, Olbe L (1989) Influence of age, fat cell weight, and obesity on $\mathrm{O}_{2}$ consumption of human adipose tissue. Am J Physiol 256:E467-E474

9. Sjöström L, Björntorp P, Vrána J (1971) Microscopic fat cell size measurements on frozen-cut adipose tissue in comparison with automatic determinations of osmium-fixed fat cells. J Lipid Res 12:521-530

10. Nedergaard J, Bengtsson T, Cannon B (2007) Unexpected evidence for active brown adipose tissue in adult humans. Am J Physiol 293: E444-E452 